\title{
Malignant Pleural Mesothelioma Detected by Endobronchial Ultrasound-Guided Transbronchial Needle Aspiration
}

\author{
EBUS Transbronşial İğne Aspirasyon Biyopsisi ile Tanı Konulan Malign \\ Plevral Mezotelyoma Olgusu
}

Aysegul Senturk', Ebru Sengul Parlak', Elif Babaoglu², Hayriye Tatli Dogan ${ }^{3}$, Hatice Canan Hasanoglu ${ }^{4}$

\begin{abstract}
A 63-year-old man was admitted to our clinic with left hilar lymphadenopathy on his chest radiography. Fluorodeoxyglucose positron-emission tomography showed multiple regions of high metabolic activity on the left pleura and left interlobar lymph nodes. Histopathological examination of the lymph node material obtained by endobronchial ultrasound-guided transbronchial needle aspiration (EBUS-TBNA) revealed malignant mesothelioma. This case report demonstrates the usefulness of EBUS-TBNA in the diagnosis of metastatic mesothelioma.
\end{abstract}

Key words: Endobronchial ultrasonography (EBUS), mediastinal lymph node, mesothelioma.

\section{Özet}

Posteroanterior akciğer grafisinde sol hiler lenfadenopati saptanan 63 yaşında erkek hasta kliniğimize başvurdu. PET-CT'de solda lenf bezlerinde ve plevrada artmış florodeoksiglukoz tutulumu saptandı. Endobronşiyal ultrason transbronşiyal iğne aspirasyonu (EBUS-TBIA) ile elde histopatoljik incelemede malign mezotelyoma saptandı. Bu olgu ile EBUS-TBNA'nın metastatik malign mezotelyoma olgularında kullanımının faydalı olduğu gösterildi.

Anahtar Sözcükler: Endobronşiyal ultrason (EBUS), mediastinal lenfadenopati, mezotelyoma.
Malignant mesothelioma is a rare and fatal neoplasm, which is strongly associated with asbestos exposure. Malignant pleural mesothelioma (MPM) arising from the parietal pleura is more frequent (65 to 70\%), as inhalation is the typical route of asbestos pathogenicity (1). Various techniques have been used for the diagnosis of MPM, including thoracentesis with pleural fluid cytology and closed pleural biopsy; however these techniques may not obtain enough tissue to confirm the diagnosis. Video-assisted thoracoscopic surgery (VATS) is recommended for a definitive diagnosis; however, VATS is an invasive and expensive technique (2) A minimally invasive procedure, endobronchial ultrasound-guided transbronchial needle aspiration (EBUS-TBNA), provides sampling of mediastinal and hilar lymph nodes, as well as centrally located lung lesions. In the literature, there is only one study in which the value of the EBUS-TBNA was investigated in the diagnosis of MPM (3). Herein, we present a case with MPM diagnosed using EBUS-TBNA.
'Department of Pulmonary Diseases, Ankara Atatürk Training and Research Hospital, Ankara, Turkey

${ }^{2}$ Department of Pulmonary Diseases, Hacettepe University, Faculty of Medicine, Ankara, Turkey

${ }^{3}$ Department of Pathology, Ankara Atatürk Training and Research Hospital, Ankara, Turkey

${ }^{4}$ Department of Pulmonary Diseases, Yıldırım Beyazıt University, Faculty of Medicine, Ankara, Turkey

\footnotetext{
'Ankara Atatürk Eğitim ve Araştıma Hastanesi, Göğüs Hastalıkları Kliniği, Ankara

${ }^{2}$ Hacettepe Üniversitesi Tıp Fakültesi, Göğüs Hastalıkları Kliniği, Ankara

${ }^{3}$ Ankara Atatürk Eğitim ve Araştırma Hastanesi, Patoloji Bölümü, Ankara

${ }^{4}$ Yıldırım Beyazı Ünversitesi, Tıp Fakültesi, Göğüs Hastalıkları Kliniği, Ankara
}

Submitted (Başvuru tarihi): 15.11.2015 Accepted (Kabul tarihi): 02.02.2016

Correspondence (iletişim): Aysegul Senturk, Department of Pulmonary Diseases, Ankara Atatürk Training and Research Hospital, Ankara, Turkey

e-mail: asenturk1967@yahoo.com 


\section{CASE}

A 63-year-old male patient with a 102-pack per year smoking history was admitted to the outpatient clinic for the evaluation of a left hilar lymphadenopathy. He did not have a history of asbestos exposure; however, he had a history of left pleural effusion from 10 years previously. No malignant cells were found after a closed pleural biopsy, followed by computed tomography (CT) once per year.

No abnormalities were found at his physical examination. Laboratory tests showed high CRP levels $(9.40 \mathrm{mg} / \mathrm{dL}$, normal level: $0-0.8 \mathrm{mg} / \mathrm{dL}$ ), and the $\mathrm{Hb}$ level was $11.3 \mathrm{~g} / \mathrm{dL}$ (normal level: $13.5-18 \mathrm{~g} / \mathrm{dl}$ ). Chest X-ray revealed a left hilar fullness, which was an enlarged hilar lymph node on the contrast-enhanced CT scan. There was pleural thickening, but no pleural effusion (Figure 1a) Fluorodeoxyglucose positron-emission tomography (FDGPET) showed multiple regions of high metabolic activity on the left pleura and left interlobar lymph node (\# 11 R).

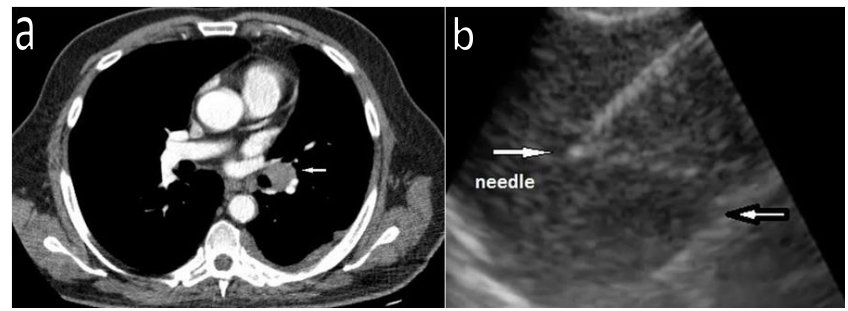

Figure 1a and b: A Chest CT scan showing an enlarged hilar lymph node and pleural thickening (a). EBUS-TBNA: Fine needle in the left interlobar lymph node (b).

Subsequently, EBUS-TBNA was performed to obtain a tissue specimen for diagnosis (Figure 1b). The cytopathological examination showed a spindle cell malignancy with vimentin. Calretinin and CD31 expression by immunohistochemistry was compatible with malignant mesothelioma (Figure $2 a$ and b). The EBUS-TBNA findings were confirmed with a tru-cut biopsy (Figure 2c).

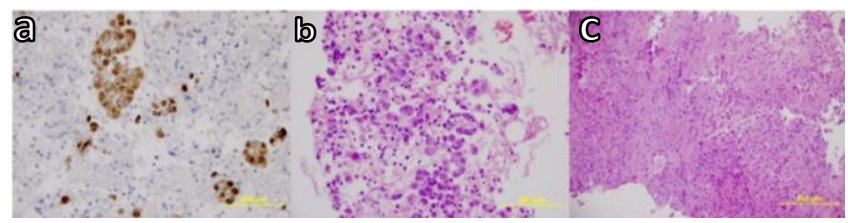

Figure $2 a, b$ and c: Nuclear and cytoplasmic positivity of calretinin in cell block (a). Single cell and groups of atypical mesothelial cells in cell block (b). Mesothelioma infiltration in pleural tru-cut biopsy (c) (H\&E x200)

\section{DISCUSSION}

Mesothelioma is the most common primary malignant tumor of the pleura. It is a very rare disease, originating from the mesothelial cells lining the pleura. Extrapleural nodal metastasis is unusual in mesothelioma, while hilar and mediastinal lymph node involvement occurs in less than $50 \%$ of the patients (1).

The pathogenesis of this disease remains unclear, as the information about the role of asbestos exposure in the development of malignant mesothelioma can not be defined for the majority of cases. In such cases, dust exposure, chemicals, genetic factors, and viral infections have been reported (4). There was no asbestos exposure in our case, either; however, our case was a chronic smoker. The rarity of the disease, the absence of asbestos exposure, and the unusual presentation prompted us to report this case.

Radiological modalities are currently available for the detection of nodal metastases in patients with MPM. Computed tomography (CT) has a sensitivity of $60 \%$ in detecting nodal involvement. In recent years, the role of FDG-PET has been increasing in the evaluation of MPM (4). However, imaging studies can not replace pathological examinations, and invasive procedures may be needed for a definitive diagnosis (4). For instance, videoassisted thoracoscopic biopsy has a high sensitivity for diagnosis; however, it is a more invasive procedure which usually requires general anesthesia. In addition, EBUSTBNA is a proven alternative to surgery for sampling mediastinal and hilar lesions. It is recognized as an accurate and minimally invasive procedure for the diagnosis of hilar and mediastinal lymph nodes (3).

As MPM is an aggressive disease, early diagnosis must be achieved for successful treatment. Despite the advances in our understanding of the pathobiology of MPM, the definitive diagnosis of MPM still requires histopathological tissue examinations, usually via direct thoracoscopic biopsy, combined with a panel of immunohistochemical markers (4). Furthermore, MPM is a very heterogeneous malignancy, often resulting in misdiagnosis with other conditions. Mesothelioma is classified into three major histological types: epithelioid, sarcomatoid and mixed. The best prognosis is in the epithelioid type, which is the most common (50 to $60 \%$ ). Clinical and radiographic evaluations alone may be often insufficient for the diagnosis, while thoracoscopy is the most of definitive method (4). 
In the literature, there are few cases about malign pleural mesothelioma diagnosed by EBUS-TBNA. In one case, EBUS-TBNA was applied to subcarinal lymph node and MPM was diagnosed (5). In our case, histological specimens were obtained from the left interlobar lymph node by EBUS-TBNA, which is a minimally invasive procedure. Therefore, we showed that EBUS-TBNA is an excellent and safe tool for obtaining adequate histological nodal tissue for examination to achieve a rapid and definitive pathological diagnosis.

\section{CONFLICTS OF INTEREST}

None declared.

\section{AUTHOR CONTRIBUTIONS}

Concept - A.S., E.S.P., E.B., H.T.D., H.C.H.; Planning and Design - A.S., E.S.P., E.B., H.T.D., H.C.H.; Supervision - A.S., E.S.P., E.B., H.T.D., H.C.H.; Funding - A.S.; Materials - H.T.D.; Data Collection and/or Processing E.B.; Analysis and/or Interpretation - H.C.H.; Literature Review - A.S.; Writing - A.S.; Critical Review - A.S.

\section{YAZAR KATKILARI}

Fikir - A.S., E.S.P., E.B., H.T.D., H.C.H.; Tasarım ve Dizayn - A.S., E.S.P., E.B., H.T.D., H.C.H.; Denetleme A.S., E.S.P., E.B., H.T.D., H.C.H.; Kaynaklar - A.S.; Mal- zemeler - H.T.D.; Veri Toplama ve/veya İşleme - E.B.; Analiz ve/veya Yorum - H.C.H.; Literatür Taraması - A.S.; Yazıyı Yazan - A.S.; Eleştirel İnceleme - A.S.

\section{REFERENCES}

1. Ray M, Kindler HL. Malignant pleural mesothelioma: an update on biomarkers and treatment. Chest 2009; 136:888-96. [CrossRef]

2. Zielinski M, Haver J, Haver L, Pankowski J, Nabialek T, Szlubowski A. Staging algorithm for diffuse malignant pleural mesothelioma. Interact Cardiovasc Thorac Surg 2010; 10:185-9. [CrossRef]

3. Rice DC, Steliga MA, Stewart J, Eapen G, Jimenez CA, Lee $\mathrm{JH}$, et al. Endoscopic ultrasound-guided fine needle aspiration for staging of malignant pleural mesothelioma. Ann Thorac Surg 2009; 88:862-8. [CrossRef]

4. Scherpereel A, Astoul P, Bass P, Berghmans T, Clayson H, de Vuyst $P$, et al. Guidelines of the European Respiratory Society and the European Society of Thoracic Surgeons for the management of malignant pleural mesothelioma. Eur Respir J 2010; 35:479-95. [CrossRefl

5. Hamamoto J, Notsute D, Tokunaga K, Sasaki J, Kojima $K$, Saeki $S$, et al. Diagnostic usefulness of endobronchial ultrasound-guided transbronchial needle aspiration in a case with malign pleural mesothelioma. Inter Med 2010; 49: 423-6. 